\title{
PENDETEKSI OTOMATIS ARAH SUMBER CAHAYA MATAHARI PADA SEL SURYA
}

\author{
Ahmad Sholihuddin \\ Universitas Islam Balitar Blitar \\ Jl. Majapahit no 4 Blitar
}

\begin{abstract}
Abstrak
Penerapan teknologi otomatis dengan menggunakan sistem mikrokontroller pada sistem pengaturan, khususnya sistem pengaturan arah sel surya agar senantiasa mengikuti arah pergeseran sumber cahaya supaya Kolektor dapat menerima sumber cahaya secara maksimal. Sistem pengatur sel surya bekerja atas dasar perbandingan antara tegangan keluaran sel surya yang masing - masing dipasang secara berseberangan dengan acuan tegangan yang telah diatur dari perangkat lunaknya. Pergerakan dari sel surya ini menggunakan satu motor stepper yang digerakkan untuk satu arah putaran, yang diatur dari perangkat lunaknya saat mencari nilai tegangan maksimal dari output sel surya. Adapun Tujuan yang ingin dicapai dalam Penelitian ini adalah memahami proses yang terjadi dan syarat - syarat yang harus dipenuhi dalam memaksimalkan penggunaan sel surya terutama dalam memperoleh keluaran tegangan yang maksimal, dan pendeteksian cahaya yang paling maksimal untuk tegangan keluaran dari sel surya.
\end{abstract}

Kata kunci: sel surya, deteksi, cahaya matahari

\section{PENDAHULUAN}

Negara Indonesia sebagai Negara tropis diberikan kelimpahan sumber daya alam yang sangat melimpah salah satunya adalah sinar matahari. Dengan semakin sedikitnya sumber daya alam yang terpakai sehingga menuntut manusia mencari sumber energy alternativ lain yang lebih baik dan ramah lingkungan dalam hal ini sinar matahari sebagai sumber energi alternativ mulai banyak dimanfaatkan dan dikembangkan penggunaannya oleh para pakar dimana yang menjadi keunggulannya adalah matahari merupakan sumber energi yang ramah lingkungan dan bebas polusi. Apalagi dengan ditemukannya sel surya sebagai perangkat yang fungsinya mengkonversikan sinar matahari menjadi besaran listrik (tegangan). Namun selama ini penggunaan matahari dinegara tropis seperti Indonesia ini belum dimanfaatkan secara optimal, salah satu contohnya pemasangan kolektor sel surya dirumah - rumah masih secara permanen sehingga kurang efektif. Hal ini disebabkan posisi matahari selalu mengalami perubahan pada setiap waktu sehingga diperlukan suatu metode yang tepat yakni suatu system otomatis pada kolektor sel surya yang menjadi tumpuan untuk mendapatkan energy panas tersebut.

Melihat permasalahan diatas maka sangat diperlukan suatu alat yang mampu mengatur arah sel surya (Solar-Cell) agar selalu menghasilkan keluaran tegangan yang maksimal pada setiap jamnya. Dari hal diatas Penulis mencoba merealisasikan alat yang dapat mengatur bagaimana arah sel surya selalu mengikuti pergeseran dari sumber cahaya. Diharapkan dengan diaturnya arah sel surya akan selalu dihasilkan keluaran tegangan dari sel surya itu maksimal, sehingga diharapkan konversi energy matahari menjadi energy listrik dapat berjalan dengan baik. 
Penulis melakukan penelitian ini untuk memahami proses yang terjadi dan syarat - syarat yang harus dipenuhi dalam memaksimalkan penggunaan sel surya terutama dalam memperoleh keluaran tegangan yang maksimal, dan pendeteksian cahaya yang paling maksimal untuk tegangan keluaran dari sel surya.

Penelitian ini menggunakan metode eksperimen dengan cara melakukan percobaan atas beberapa bagian seperti pengkondisian sinyal, baik dari sel surya maupun dari pengubahan sinyal analog menjadi digital dengan menggunakan ADC 0808, penggerak motor stepper. Setelah eksperimen pada setiap komponen, dilakukan Desain dan perancangan perangkat keras maupun perangkat lunak. Dan terakhir dilakukan Uji coba alat untuk pembuktian bahwa setiap saat intensitas sinar matahari yang mengenai permukaan bumi selalu berubah dan alat dapat merespon dengan baik.

\section{PERANCANGAN ALAT}

Pada alat ini sistem pengendaliannya terdapat pada besarnya intensitas yang didapat pada sel surya, karena dari besaran cahaya oleh sel surya itu yang langsung diubah dalam bentuk besaran listrik (tegangan). Kondisi untuk memonitor pada saat adanya perubahan besar intensitas cahaya pada sel surya dapat terlihat pada indikator-indikator lampu serta adanya pergerakan / perputaran pada penampang. Secara normal alat ini langsung bekerja secara otomatis, yaitu seluruh sistem akan bekerja tanpa operator yang mengendalikannya. Besaran cahaya yang datang dan ditangkap oleh sel surya akan langsung diinterpretasikan sebagai besaran listrik (tegangan) yang dapat dideteksi oleh sel surya. Dengan demikian sel surya tersebut telah mendapatkan suatu besaran listrik analog yang menandakan sel surya tersebut telah menjadi sebuah sumber tenaga. Penempatan sel surya yang berseberangan ini digunakan untuk mencari selisih tegangan yang terdapat pada kedua sel surya. Perbedaan besar masing - masing sel surya mengindikasikan bahwa setiap sel surya mendapatkan intensitas cahaya yang berbeda. Perbandingan besar tegangan masing - masing sel surya ini yang akan mengatur arah putaran motor stepper untuk mendapatkan besar nilai intensitas cahaya pada sel surya menjadi sama besarnya. Untuk pengaturan besar intensitas dan arah putaran motor stepper diproses dalam mikrokontroler, dengan mengambil secara berurutan masukan tegangan analog pada sel surya yang sebelumnya telah diubah dalam kode digital oleh ADC (Analog-Digital Converter).

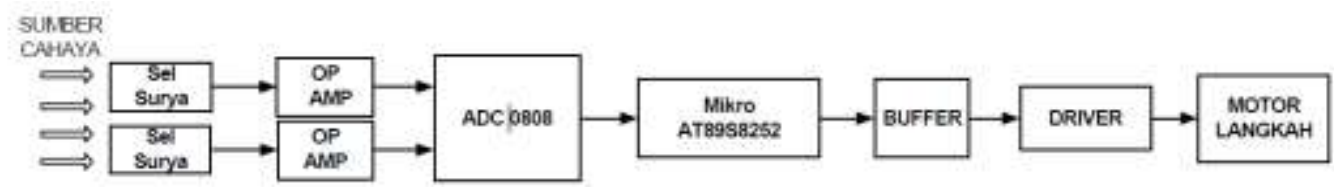

Gambar 3.1 Blok diagram perancangan alat.

Digital Converter (ADC 0808). Hasil dari pengubahan analog kedigital ini berupa data biner yang akan digunakan sebagai perbedaan besar intensitas dan sebagai acuan untuk arah putaran motor stepper. Untuk diagram alir pada perubahan pengambilan data analog pada sel surya dapat dilihat pada gambar 3.3. 


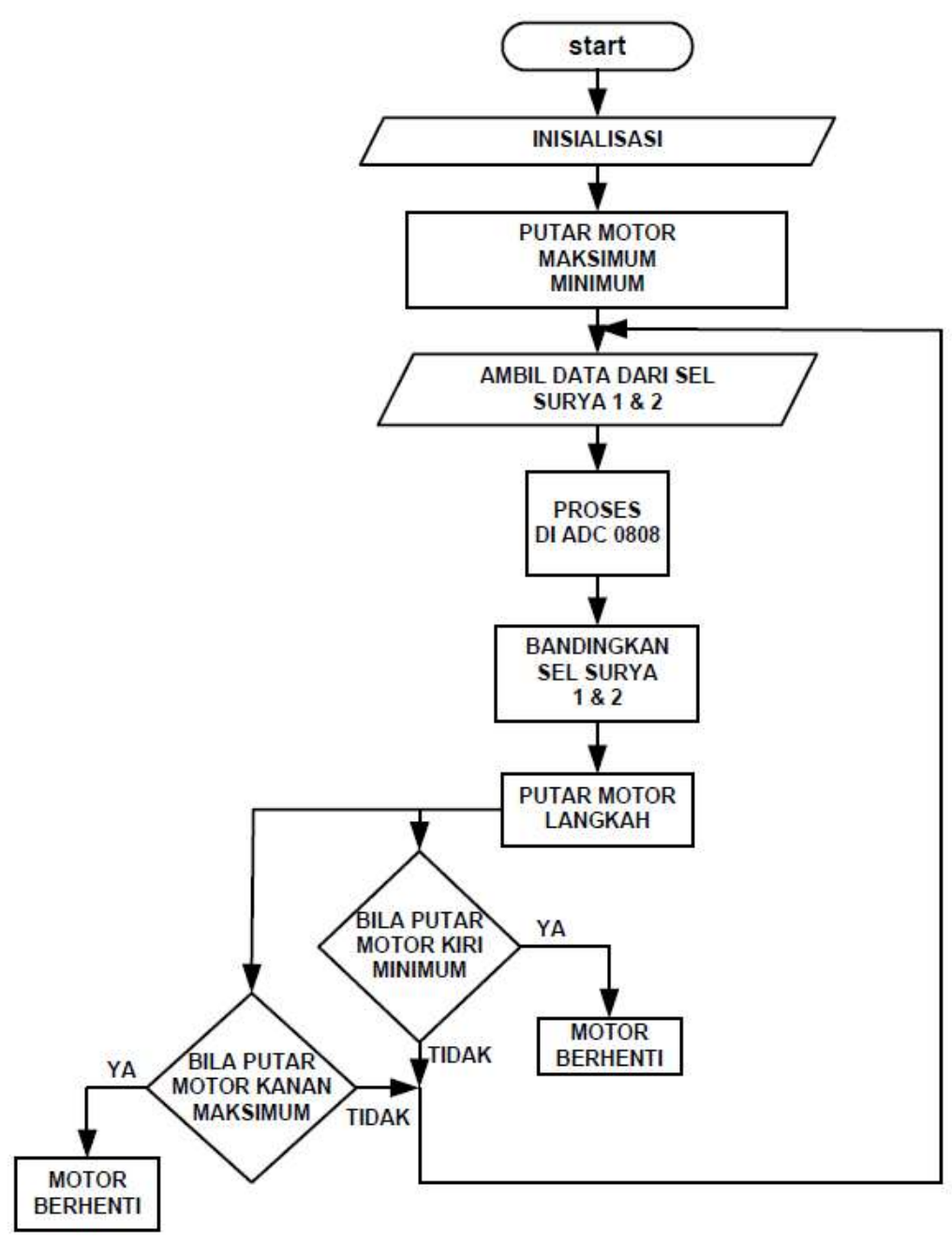

Gambar 3.2 Diagram alir utama.

Diagram alir pada gambar 3.3 merupakan lanjutan atau masih berhubungan dengan diagram alir utama diatas. Proses lanjutannya ada pada bagian pengolahan ambil data analog, proses di ADC serta pembandingan data ADC kedalam mikrokontroler. Diagram alir perubahan tegangan sel surya menjelaskan bagaimana pengambilan data - data analog yang diolah oleh ADC menjadi data biner. Pengelompokkan besaran analog dari tegangan tertinggi sel surya sebesar 2,50 volt sampai 2,16 volt dan seterusnya dilakukan agar sistem pada pengolahan di ADC dan mikrokontroler mendapatkan besaran data biner yang sesuai. Maka sistem perancangan ini melakukan pengelompokkan pada pemrogrammannya untuk mendapatkan data biner yang lebih baik dan tepat, kemudian data tersebut akan disimpan pada register di mikrokontroler. 


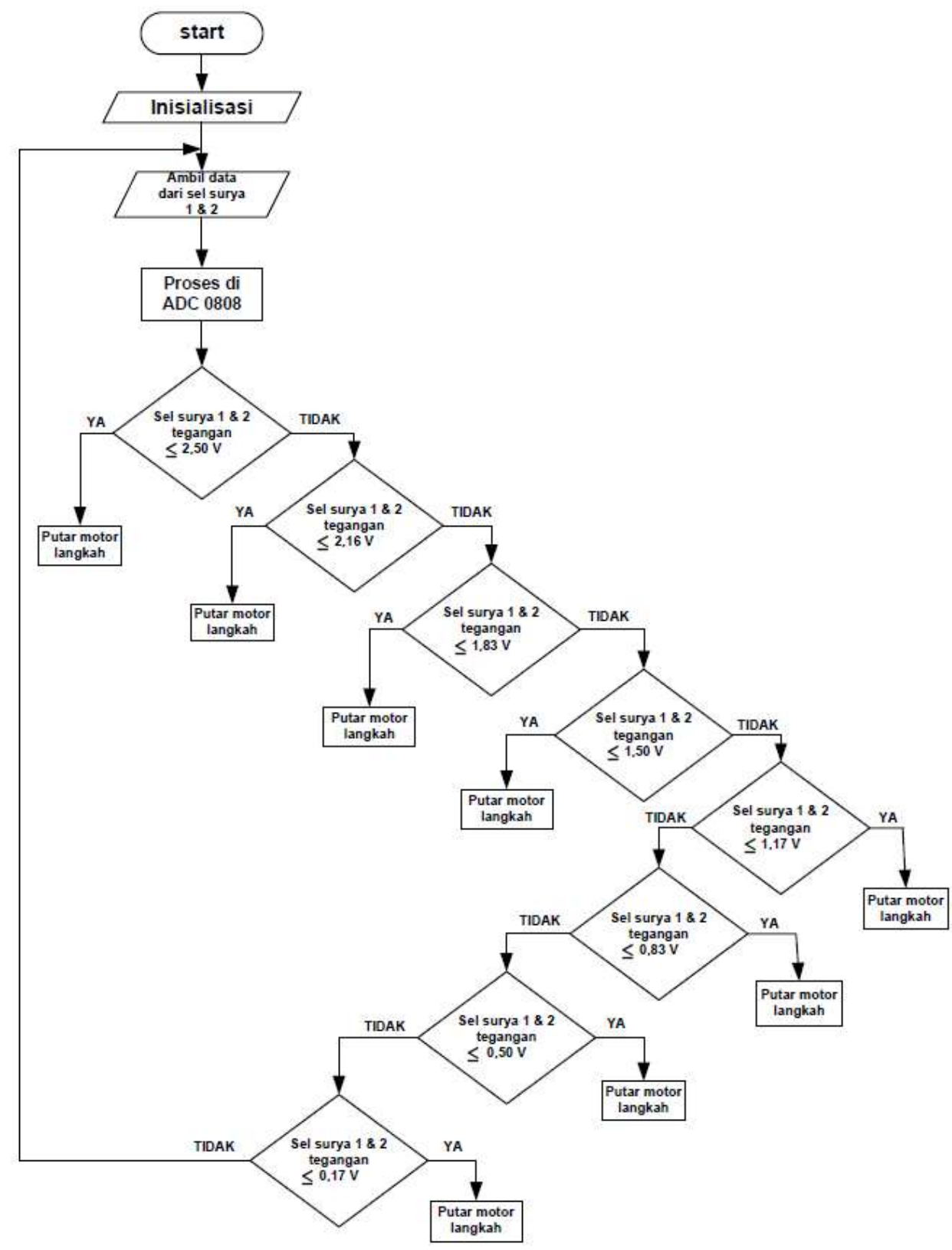

Gambar 3.3 Diagram alir perubahan tegangan sel surya.

\subsection{Rangkaian Pembangkit Pulsa ADC 0808}

Rangkaian pembangkit pulsa yang digunakan sebagai clock ADC 0808, adalah IC 74LS04. IC ini merupakan inverter yang diharapkan dapat diperoleh pulsa yang dapat digunakan sebagai pembangkit pulsa ADC. Dimana pembangkit pulsa ini sangat dibutuhkan dalam rangkaian digital.

Besarnya nilai frekuensi clock yang masih diperbolehkan (min $10 \mathrm{kHz}$, maks $1280 \mathrm{kHz}$ ). Untuk nilai frekuensinya clocknya rata - rata $=500 \mathrm{kHz}$, jika diasumsikan nilai kapasitor yang dipakai adalah $\mathrm{C}=680 \mathrm{pF}$, maka diperoleh nilai $\mathrm{R}=2.6 \mathrm{k} \Omega$ 
Dari perhitungan nilai $\mathrm{R}=2,6 \mathrm{k} \Omega$, maka nilai frekuensi clock yang digunakan adalah 500 $\mathrm{kHz}$ sebagai input clock ADC. Pemilihan ADC 0808 sebagai pengubah analog ke digital, karena ADC ini mempunyai 8 masukan tegangan analog dan 8-bit keluaran kode digital yang sesuai (compatible).

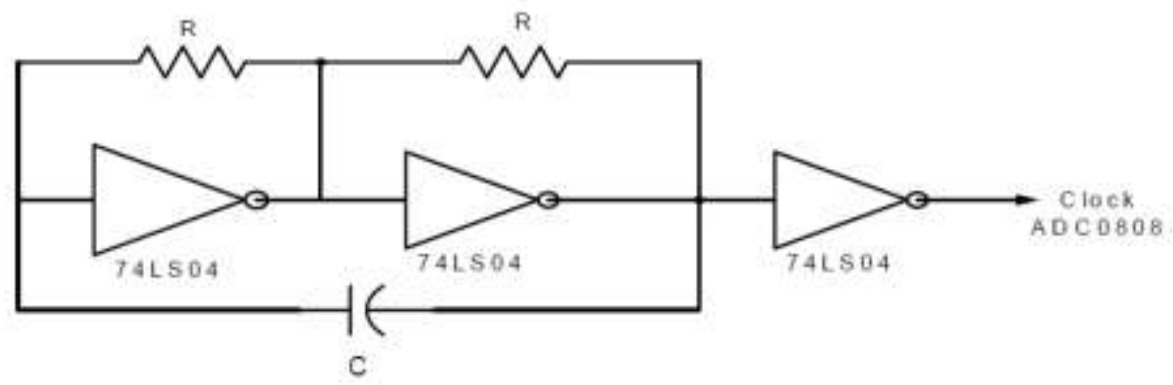

Gambar 3.4 Pembangkit pulsa ADC 0808.

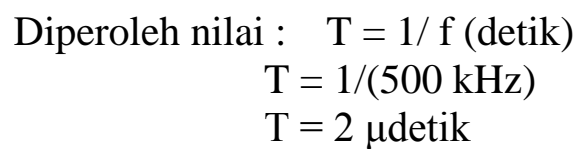

Waktu pengubahan rata - rata $=\mathrm{N}-$ bit $\mathrm{x}$ frekuensi clock

$$
\begin{aligned}
\text { Dimana } ; \mathrm{N}-\text { bit } & =\text { jumlah banyaknya bit } \\
\text { Frekuensi clock } & =\text { frekuensi yang digunakan sebagai } \\
& \text { pembangkit clock ADC } \\
\text { waktu pengubahan rata }- \text { rata } & =8 \times 2 \mu \text { detik } \\
& =1,6.10 \text {-detik }
\end{aligned}
$$

\subsection{Perancangan Perangkat Lunak}

Pada perancangan ini pengaturan dari awal dilakukan langsung secara otomatis yang artinya program yang dibuat untuk mengatur arah perputaran motor stepper yang menentukan posisi dari sel surya serta menentukan titik batas pergerakan permukaan sel surya diatur secara otomatis, dimana arah pergerakan motor stepper didasarkan pada perbandingan input tegangan dari dua buah sel surya yang terpasang. Motor yang digunakan hanya satu arah pergerakan yang menggerakkan sel surya. Secara terperinci tahapannya akan dijelaskan sebagai berikut ini :

Pertama, baca ADC untuk output tegangan sel surya kesatu dan kedua yang menjadi input analog ADC, sampai terjadi konversi analog kedigital.

Kedua, setelah terjadi konversi, kedua input ADC tadi dibandingkan. Jika input tegangan kesatu memiliki harga lebih besar dari yang kedua atau sebaliknya maka motor stepper akan bergerak pada arah yang ditentukan sampai kedua sel surya mencapai pada kondisi input tegangan yang sama besarnya.

Ketiga, bila besaran input tegangan kedua sel surya sama besar maka instruksi pada motor stepper akan diam sampai tercapai kembali besaran input tegangan sel surya berbeda maka motor stepper akan bergerak pada arah yang ditentukan.

Keempat, sel surya akan terus melakukan hal yang sama seperti pada urutan pertama yaitu membandingkan input tegangan yang didapat. Dengan begitu motor stepper akan terus berputar apabila ada perbedaan tegangan sel surya. 


\subsection{Metode Pengambilan Data Keluaran ADC}

Harga tegangan yang terjadi pada tiap sel surya sangat bervariasi bila bidang permukaan sel surya mendapatkan intensitas cahaya yang berubah - ubah. Keluaran sel surya berupa tegangan yang akan diubahkan di ADC menjadi keluaran yang berbentuk data biner. Besaran tegangan yang terjadi pada tiap titik sel surya bergantung pada besar intensitas yang tertangkap oleh sel surya. Bila disesuaikan dengan hasil percobaan semakin besar permukaan sel surya mendapat intensitas cahaya maka akan semakin besar tegangan yang dihasilkan oleh sel surya bergantung pada komposisi tegangan maksimum yang dapat dicapai oleh sel surya.

Algoritma yang digunakan untuk pengambilan data sel surya 1 atau sel surya 2 adalah sebagai berikut. Pertama pilih ADC pada sel surya 1, begitu juga ADC pada sel surya 2 . Kemudian mengambil data biner pada ADC, sebelumnya telah dipilih jalur alamat untuk masukan analog. Lalu mikrokontroler memberikan keluaran tinggi ke START dan ALE pada ADC, setelah itu ADC memberikan logika tinggi pada EOC untuk mengisyaratkan waktu pengkonversian dari analog ke digital, bilamana mikrokontroler mendapat logika rendah oleh ADC menandakan sudah selesainya waktu pengkonversian.

Data biner yang telah didapatkan disimpan pada akumulator pada mikrokontroler. Data biner inilah yang dijadikan sebagai data untuk pembanding antara kedua sel surya. Begitu juga dengan pengambilan data biner sel surya 2 sama dengan pada sel surya 1.

\subsection{Penentuan Posisi Putaran Maksimum}

Pada alat ini dirancang juga untuk mengkontrol arah pergerakan putaran maksimum motor yang diatur melalui perangkat lunaknya. Pada awal kerja alat ini motor melakukan putaran searah jarum jam dan sebaliknya untuk menentukan batas putar maksimal yang dapat dilakukan. Penentuan ini merupakan penentuan posisi titik awal pada penampang untuk pergerakan selanjutnya. Untuk pengaturannya berikut ini algoritma untuk mendeteksi arah maksimal putaran penampang. Pertama ditentukan dahulu besar absolut pada register 7, kemudian register 7 ditambah terus sampai datanya mencapai $62 \mathrm{H}$. Putaran motor berlangsung bersamaan dengan pertambahan data di register 7 .

\subsection{Pengaturan dan Pengambilan Arah Putaran Motor}

Rutin ini menentukan arah putaran motor secara otomatis mencari posisi kepingan antara sel surya berada pada besar sumber intensitas yang sama. Untuk menentukan arah putaran motor searah jarum jam atau sebaliknya dan mengatur agar posisi kepingan antar sel surya memperoleh besaran intensitas yang sama maka pengaturannya pada algoritma dibawah ini.

Algoritma menentukan arah putaran motor secara otomatis yang membandingkan antara besar sel surya 1 dan sel surya 2 . Data didapat pada sel surya1 dan sel surya2. Kemudian data yang didapat pada sel surya 1 dan sel surya 2 dibandingkan untuk menentukan arah putaran motor kekanan atau kekiri. Bila besar intensitas pada sel surya 1 dan sel surya 2 sama besar maka motor tidak bergerak / diam.

\section{PENGUKURAN DAN ANALISIS}

Sistem pengendalian pada alat ini dirancang untuk memperoleh sistem pengendalian arah putaran motor stepper sebagai penggerak panel sel surya sebagai aktuator penentu arah datangnya sumber cahaya. Untuk memperoleh hasil pengamatan dilakukan pengukuran untuk mendapatkan data - data dari alat yang dibuat, untuk selanjutnya dapat spesifikasi akhir dari 
alat yang dibuat. Percobaan dilakukan pengujian kemampuan keluaran sel surya terhadap sumber cahaya yang didapatkan.

Dalam perancangan bagian sensor yang digunakan ini ada 3 faktor yang harus diperhatikan, terutama menyangkut tegangan keluaran dari sel surya itu sendiri, yaitu :

\section{Intensitas Penyinaran}

Besarnya intensitas penyinaran yang mengenai permukaan dari sel surya akan berpengaruh terhadap tegangan keluarannya, karena sifat dari bahan dasar sel surya yaitu silicon yang merupakan sambungan $\mathrm{p}$ dan $\mathrm{n}$. sehingga dengan meningkatkan intensitas penyinaran akan mengakibatkan elektron memiliki energi vibrasi yang lebih besar.

\section{Sudut Penyinaran}

Semakin besar sudut penyinaran yang mengenai permukaannya akan semakin besar tegangan keluarannya, karena cahaya yang mengenainya akan tersebar merata diseluruh bidang permukaan sel surya.

\section{Jarak Penyinaran}

Dengan semakin dekat penyinaran akan mempengaruhi keluaran tegangan sel surya karena kuat cahaya yang mengenai permukaannya akan makin besar.

Grafik 3.1 memperlihatkan data perhitungan kuat cahaya terhadap jarak dengan menggunakan lampu bohlam $(60 \mathrm{~W})$, sehingga diperoleh grafik jarak penyinaran terhadap kuat cahaya.

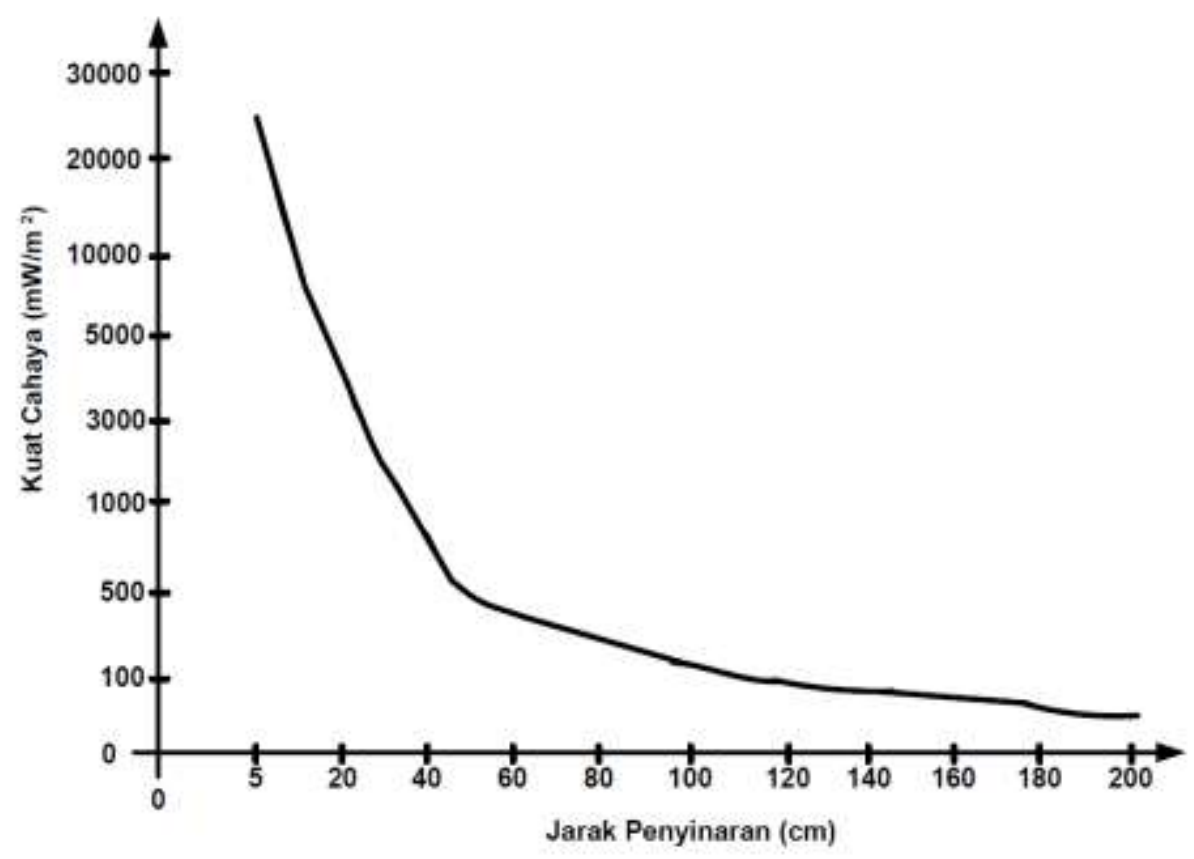

Gambar 3.1 Grafik hubungan kuat cahaya terhadap jarak penyinaran. 


\subsection{Pengujian Output Tegangan Sel Surya}

Pengujian dilakukan dengan mengambil data - data output tegangan sel surya untuk dua sistem pemasangan kolektor sel surya, diantaranya pemasangan kolektor sel surya permanen dan yang diatur arahnya, sehingga kita dapat menentukan salah satu sistem pemasangan yang memberikan hasil lebih maksimal dari pengujian tersebut.

Pengambilan data dilakukan dengan cara menggunakan lampu bohlam $60 \mathrm{~W}$, sebagai simulasi sumber cahaya yang digerakkan secara manual pada jarak lampu yang tetap terhadap bidang kolektor sel surya sepanjang $30 \mathrm{~cm}$ dengan besar sudut yang berbeda - beda yaitu $0^{0}$ sampai $180^{\circ}$ dimana bidang kolektor sel surya diambil sebagai acuan awal sudut.

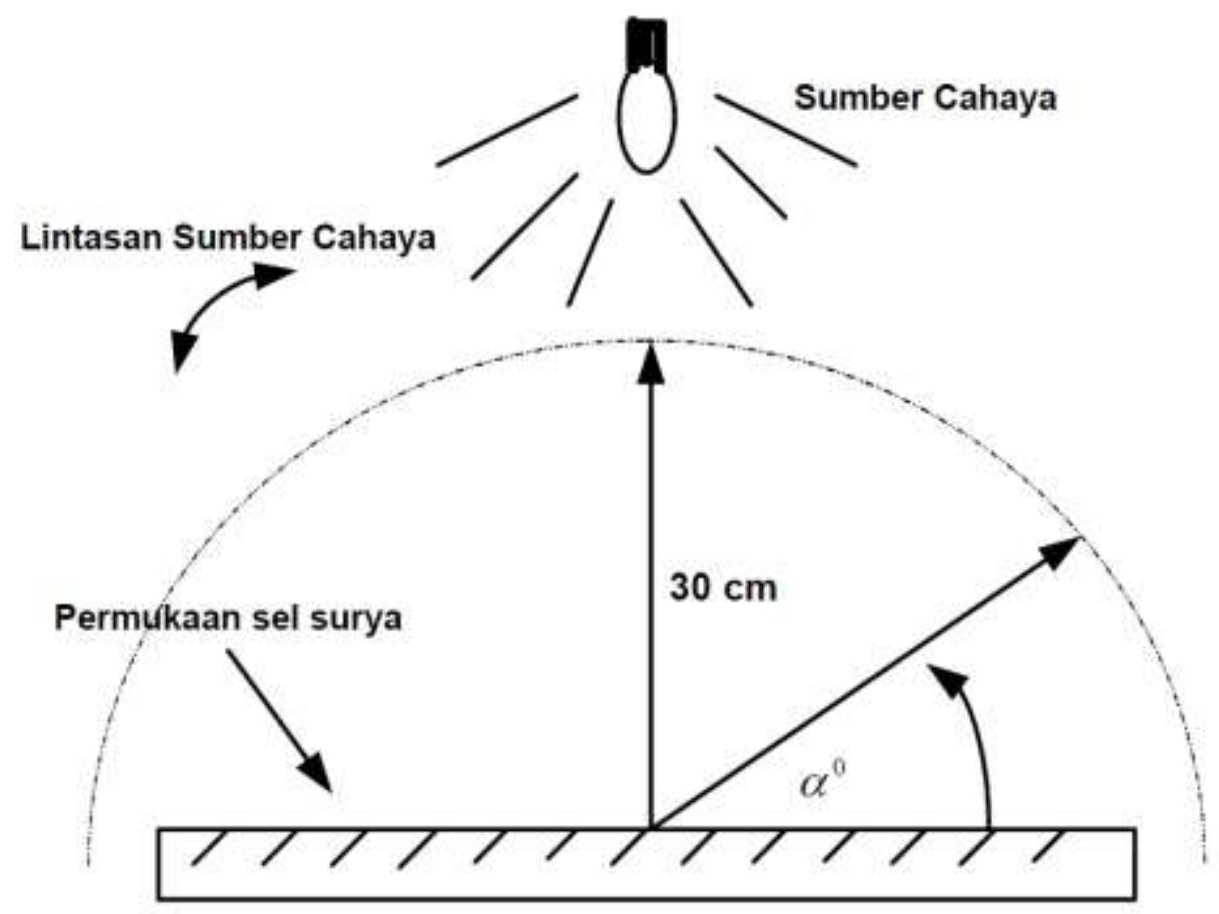

Gambar 3.2 Cara pengujian output tegangan sel surya.

\subsubsection{Pemasangan Secara Permanen}

Data keluaran tegangan sel surya pada sistem pemasangan permanen dapat dilihat di Gambar 3.3 dimana posisi kolektor sel surya dibuat tetap dalam beberapa sampel data sudut yang berbeda-beda.

\subsubsection{Pemasangan Tidak Permanen (Dapat Diatur)}

Pada pengujian ini kolektor sel surya bergerak secara otomatis dengan posisi kolektor selalu relatif tegak lurus cahaya bohlam pada setiap sampel sudut yang berbeda - beda dan datanya dapat dilihat pada Gambar 3.4. 


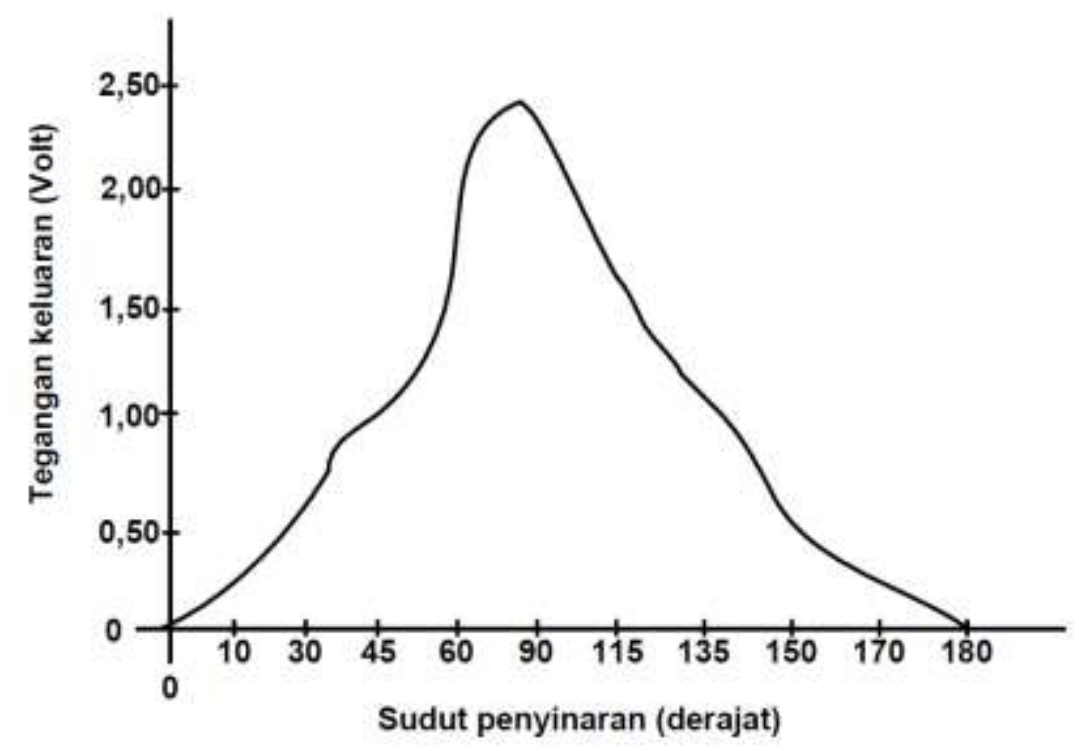

Gambar 3.3 Grafik keluaran penerimaan sel surya yang dipasang permanen.

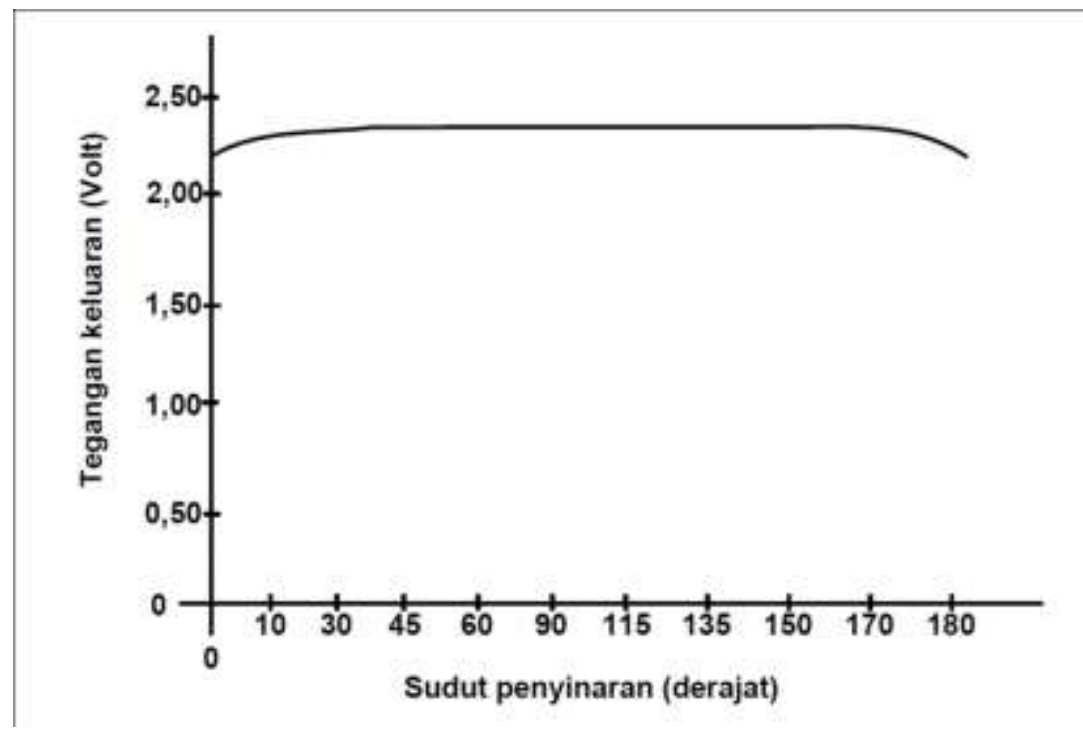

Gambar 3.4 Grafik keluaran penerimaan sel surya pemasangan tidak permanen.

Dari kedua sistem pemasangan tersebut akan didapat rata - rata tegangan keluaran :

1. Keluaran tegangan sel surya permanen (tetap)

Rata - rata tegangan keluaran sel surya : 0,93 volt

Presentase keluaran tegangan yang diperoleh adalah : 37,2\%

2. Keluaran tegangan sel surya yang tidak permanen (dapat diatur)

Rata - rata tegangan keluaran sel surya : 2,37 volt

Presentase tegangan keluaran yang diperoleh adalah : 94,8 \%

Didapat selisih perbandingan antara keluaran tegangan sel surya yang dipasang permanen dengan yang diatur arahnya sebesar : $(95,0 \%-38,0 \%)=57,0 \%$. Yang berarti akan sangat 
efektif penggunaan pengatur arah sel surya ketika suatu sistem memerlukan keakuratan yang tinggi.

\subsection{Pengujian Terhadap Dua Buah Sel Surya}

Pada percobaan ini mengukur dan membandingkan suatu kejadian antara dua buah sel surya yang dipasang berseberangan membentuk suatu sudut $45^{\circ}$ terhadap bidang landasan yang diperlihatkan pada gambar 3.5. Percobaan yang dilakukan masih menggunakan bohlam lampu sebagai sumber cahaya.

Pada gambar 3.5 terlihat peletakan sumber cahaya yang tidak tegak lurus terhadap landasan permukaan. Tampak pemasangan sel surya yang berseberangan agar didapatkan perbedaan besar intensitas yang didapat pada tiap permukaan sel surya. Perbedaan ini menghasilkan besar tegangan yang berbeda juga pada tiap sel surya. Pada percobaan diatas pengukuran dilakukan pada jarak $30 \mathrm{~cm}$, dimana pada jarak ini diambil untuk posisi jarak yang ideal. Bila jaraknya terukur dibawah $20 \mathrm{~cm}$ maka kedua sel surya tersebut akan mengalami kejenuhan.

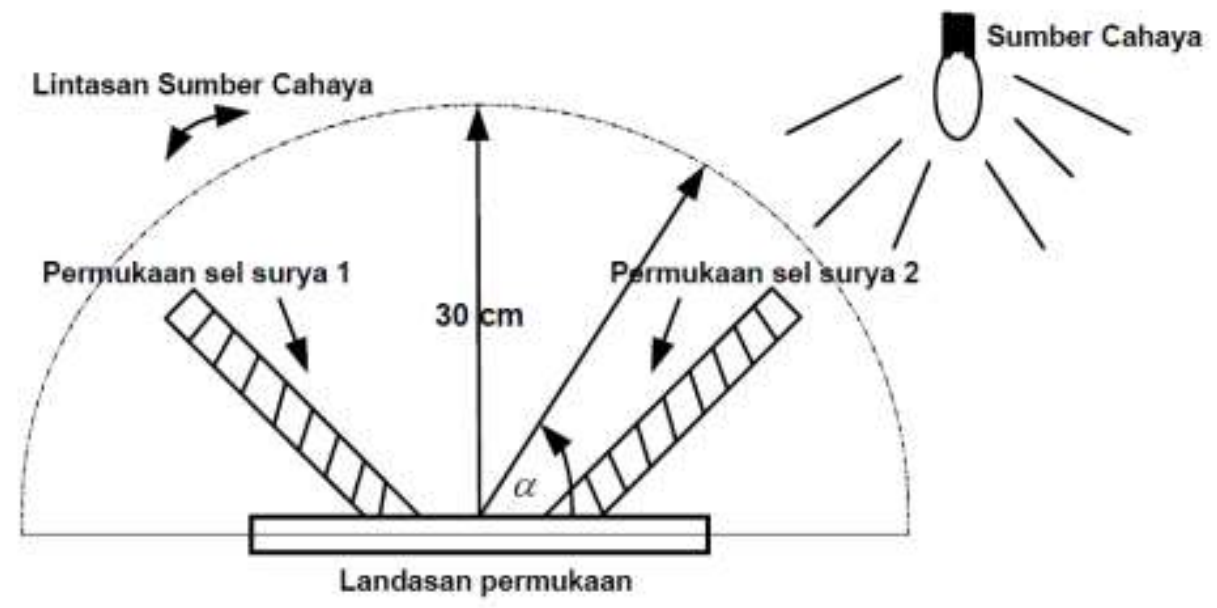

Gambar 3.5 Pengujian terhadap dua buah sel surya

Tabel 3.1 ialah hasil pengukuran tegangan tiap sel surya berdasarkan gambar 3.5. Tabel tersebut menunjukkan tegangan pada sel surya 1 akan lebih besar daripada tegangan sel surya 2, karena pada gambar terlihat permukaan sel surya 1 lebih terkenai oleh pancaran sumber cahaya. Pengukuran dilakukan pada jarak $30 \mathrm{~cm}$, setelah itu diambil besar tegangan dengan mengatur sudut pancaran sumber cahayanya. Dengan demikian untuk menyamakan besar tegangan pada sel surya 1 dan sel surya 2, sumber cahaya harus berada pada posisi tegak lurus terhadap landasan yaitu pancaran sumber cahaya merata terpancar pada permukaan sel surya 1 dan sel surya 2.

Bila pengukuran dilakukan pada jarak yang lebih jauh maka besar pancaran sumber cahaya akan berkurang mengenai permukaan sel surya yang dapat juga menyebabkan berkurangnya kemaksimalan tegangan keluaran pada sel surya tersebut. Percobaan pada gambar 3.5 juga akan sama bila sumber cahaya diubahkan pada arah yang berlawanan, hanya permukaan sel surya 2 yang akan banyak terkenai pancaran sumber cahaya dibanding permukaan sel surya 1 sehingga besar tegangan sel surya 2 akan lebih besar dibanding sel surya 1 . 
Tabel 3.1 Data pengukuran tegangan dua sel surya yang diukur berseberangan.

\begin{tabular}{|c|c|c|}
\hline $\begin{array}{c}\text { Sudut } \\
\text { (Derajat) }\end{array}$ & $\begin{array}{c}\text { Sel Surya 1 } \\
\text { (volt) }\end{array}$ & $\begin{array}{c}\text { Sel Surya 2 } \\
\text { (volt) }\end{array}$ \\
\hline 0 & 0,75 & 0,46 \\
\hline 10 & 1,71 & 0,64 \\
\hline 20 & 2,00 & 0,89 \\
\hline 30 & 2,05 & 1,21 \\
\hline 40 & 2,17 & 1,50 \\
\hline 50 & 2,21 & 1,67 \\
\hline 60 & 2,24 & 1,89 \\
\hline 70 & 2,26 & 2,15 \\
\hline 80 & 2,29 & 2,25 \\
\hline 90 & 2,30 & 2,29 \\
\hline
\end{tabular}

\section{KESIMPULAN DAN SARAN}

\subsection{Kesimpulan}

Beberapa kesimpulan yang dapat diambil dari pembuatan alat ini adalah sebagai berikut :

1. Sel surya selain berfungsi sebagai piranti konversi energi dapat digunakan secara optimal sebagai sensor.

2. Sistem pengatur sel surya bekerja atas dasar perbandingan antara tegangan keluaran sel surya yang masing - masing dipasang secara berseberangan dengan acuan tegangan yang telah diatur dari perangkat lunaknya.

3. Pergerakan dari sel surya ini menggunakan satu motor stepper yang digerakkan untuk satu arah putaran, yang diatur dari perangkat lunaknya saat mencari nilai tegangan maksimal dari output sel surya.

4. Dari hasil pengamatan (grafik penerimaan sel surya) selisih presentasi keluaran tegangan yang dihasilkan sel surya pemasangan permanen dengan pemasangan tidak permanen (dapat diatur) sebesar $67,0 \%$.

\subsection{Saran}

1. Diperlukan suatu sisitem mekanik yang sangat baik untuk mendukung sistem secara keseluruhan baik motor yang digunakan juga penampang pada peletakan sel surya agar lebih baik.

2. Putaran motor stepper yang baik menggunakan sudut pergerakan yang lebih presisi lagi agar diperoleh sudut intensitas yang optimal.

\section{DAFTAR PUSTAKA}

Arismunandar, W. (1995). Teknologi Rekayasa Surya. Jakarta: PT. Pradnya Paramita. Eko Putra, A. (2002). Belajar Mikrokontroler AT89C51/52/55 (Teori dan Aplikasi).

Yogyakarta: Gava Media.

J, D. (1989). Operasional Amplifier and Integrated Circuit. New York: Mc Graw - Hill.

Malik, M. I. (2003). Belajar Mikrokontroler ATMEL AT89S8252. Yogyakarta: Gava media. 
S.I, M. (1995). The 8051 microcontroller. New Jersey: Prentice Hall.

Syamsuarnis, \& Amran, G. ( 1997 ). Teknik Iluminasi. Padang: Fakultas Pendidikan

Teknologi dan Kejuruan Institut Keguruan dan Ilmu Pendidikan Padang.

Uffenbeck, J. (1991). Microcomputers And Microprocessors (International Editions ed.). New Jersey: Prentice Hall. 